\title{
Dermatoglyphic Patterns in Sickle Cell Anaemia Patients of Chhattisgarh, India
}

\section{Shetty RM * and Sarda R}

Department of Pedodontics and Preventive Dentistry, Chhattisgarh Dental College and Research Institute, India

*Corresponding author: Raghavendra M Shetty, Department of Pedodontics and Preventive Dentistry, Chhattisgarh Dental College and Research Institute, India, Tel: +91 9993987421; Fax: +91 7744 281930; E-mail: raghavendra77@yahoo.com

\section{Research Article}

Volume 2 Issue 3

Received Date: March 04, 2017

Published Date: August 14, 2017

DOI: $10.23880 /$ oajds-16000141

\section{Abstract}

Objectives: Dermatoglyphics is useful in the management of various genetic disorders. Sickle cell anemia is a genetic disorder of early age which in severe forms needs blood transfusion. Prevalence of sicklers is around 10\% in Chhattisgarh, India population. One can diagnose the cases of sickle cell anemia by dermatoglyphics which deals with the study of epidermal ridges. This non invasive tool for diagnosis will prove to be a boon to sicklers and will help for creating their healthy future.

Materials and Methods: Seventy five children with sickle cell anemia and seventy five healthy children were included in the study. Palmar dermatoglyphic patterns of all the children were studied by photographs taken by high definition resolution digital camera. Atd angle, a-b ridge count and palmer fingertip patterns were noted and compared across the groups.

Result: The digital palmar configurations were statistically varied in the sickle group and control group. Atd angle and ab ridge count was also increased in sickle group when compared to the control.

Conclusion: Specific differences in patients of sickle cell disease as far as palmer dermatoglyphic patterns are concerned are observed. The knowledge will be useful and will aid in the diagnosis of the sickle cell disease.

Keywords: Palmar dermatoglyphics; Sickle cell disease; Fingertip pattern; "atd” angle; a-b ridge

\section{Introduction}

Early diagnosis allows the person and family to attribute cognitive changes to the disease rather than to personal failings thereby preserving the person's ego throughout the disease process. Various diagnostic aids like blood investigations and tests to detect sickle cell genes before birth are available but both are invasive tests. Dermatoglyphics which is commonly known as "skin carvings" is a term coined by Cummins \& Midlo [1] in 1926 that aptly reflects the physical manifestations of the palmar as well as plantar surfaces of all primates [1]. William Hereschel was first to experiment with fingertip patterns in India [2]. Sickle cell disease (SCD) is an autosomal recessive genetic blood disorder, characterized by red blood cells that assume an abnormal, rigid, sickle shape. Sickle cell anemia (SCA) is genetic disease that results from substitution of valine from glutamic acid in 
the $\beta$-globulin chain of the haemoglobin molecule [3]. In India the $\beta$ gene is more prevalent and prevalence rate varies from $0-40 \%$ in different population group. Chhattisgarh state is also believed to have a higher prevalence rate of $14-22 \%$, [4]. Dermatoglyphics has also shown positive correlation in a number of genetic diseases and hence this study was framed. Genetic linkage and determination of dermatoglyphics is apparent [5], and it has in fact been described one of the best available diagnostic tool in genetic disorders [6].

\section{Materials and Methods}

In this prospective study, seventy five children aged 413 years pre-diagnosed with sickle cell anemia from the sickle units of District Hospital and seventy five healthy children aged 4-13 years reporting to the Department of Pedodontics and Preventive Dentistry were included in the study. The diagnosis of the sickle cell was made by physicians and pediatricians of respective departments of District hospital after thorough clinical examinations, laboratory investigations and past medical records. Ethical clearance was obtained from the committee where the study was conducted. Hands were thoroughly washed with water and soap and dried before screening for dermatoglyphics in order to remove the dirt from their hands. Photographs of both the palm were taken by high definition resolution digital camera. Palmar dermatoglyphic patterns of all the children were obtained by the ink and paper method which was originally demonstrated by Cummins [1]. Ink was applied over the palm by a roller and the palms were placed over a white paper sheet. Dermatoglyphic examinations are performed using magnifying hand lens and ridge counting was done with the help of a sharp needle. Palmer fingertip patterns, Atd angle and a-b ridge count and were noted and compared across the groups. In case of any confusion the photographs were used for verification.

\section{Palmer Fingertip Patterns}

Three basic finger patterns i) Arches (Figure 1a); ii) Loops (Figure 1b) and; iii) Whorls (Figure 1c) were counted and recorded. No distinction was made between the varieties of Arches, Loops and Whorls in the present study.
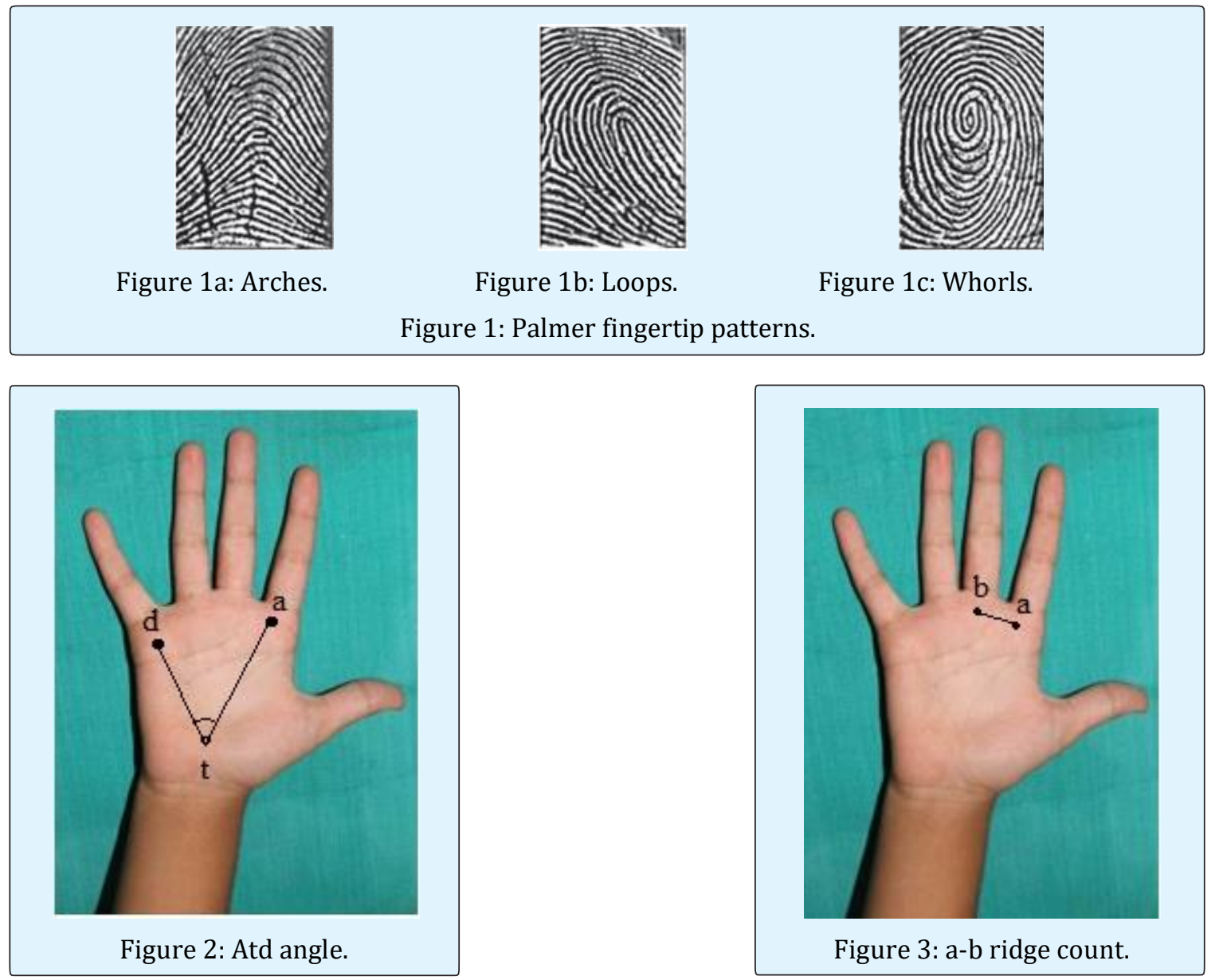


\section{Open Access Journal of Dental Sciences}

Atd angle (Figure 2)

An angle formed by lines drawn from the digital triradius (a), to axial triradius ( $\mathrm{t}$ ) and from this to digital triradius (d) which is called atd angle. The more distal the position of $t$ more would be the atd angle.

a-b ridge count (Figure 3 )

A straight line from digital triradius (a) and digital triradius (b) was drawn. Number of ridges crossing the digital triradius (a) and digital triradius (b) were called as $\mathrm{a}-\mathrm{b}$ ridge count.

\section{Statistical Analysis}

Categorical variables (percentages and frequencies) were analysed using Pearson's Chi square test. For comparison between Sickle cell patient group and control group for Age, 'atd' angle and 'a-b' ridge count (continuous variables), parametric test namely Unpaired t-test was applied. $P$ values $<0.05$ were considered statistically significant. Data analysis was done using Statistical Package for Social Sciences (SPSS) v.21.

\section{Results}

\section{Digital Fingertip Patterns}

In males of sickle group (SS) Loop (64.25\%) fingertip pattern was most dominant followed by Whorls (24.50\%) and Arches (11.25\%) being the least while in the control group whorls (52.45\%) predominated followed by loops $(32.86 \%)$ and lastly arches (14.69\%). In females of sickle group loop (63.43\%) fingertip pattern was most dominant followed by whorls (28.57\%) and arches $(08.00 \%)$ being the least, while in the control group whorls (54.23\%) predominated followed by loops (34.61\%) and lastly arches (11.15\%) (Table 1). The individual fingertip patterns were analyzed and differentiated among males and females and it was noted that the D3 (digit 3) of left hand in males were predominated by Arches (52.50\%) while D1 (digit 1) of left hand in females were predominated by Whorls (60\%) in the sickle group (Tables $2 \& 3$ ).

\begin{tabular}{|c|c|c|c|c|c|c|}
\hline \multirow{2}{*}{$\begin{array}{c}\text { Fingertip } \\
\text { Pattern }\end{array}$} & \multicolumn{3}{|c|}{ Sickle cell patients (SS) } & \multicolumn{3}{c|}{ Controls (C) } \\
\cline { 2 - 7 } & Male & Female & Total & Male & Female & Total \\
\cline { 2 - 7 } & $\mathrm{n}(\%)$ & $\mathrm{n}(\%)$ & $\mathrm{n}(\%)$ & $\mathrm{n}(\%)$ & $\mathrm{n}(\%)$ & $\mathrm{n}(\%)$ \\
\hline Loops & $257(64.25)$ & $222(63.43)$ & $479(63.87)$ & $161(32.86)$ & $90(34.61)$ & $251(33.47)$ \\
\hline Whorls & $98(24.50)$ & $100(28.57)$ & $198(26.40)$ & $257(52.45)$ & $141(54.23)$ & $398(53.07)$ \\
\hline Arches & $45(11.25)$ & $28(8.00)$ & $73(9.73)$ & $72(14.69)$ & $29(11.15)$ & $101(13.47)$ \\
\hline Total & $400(100.0)$ & $350(100.0)$ & $750(100.0)$ & $490(100.0)$ & $260(100.0)$ & $750(100.0)$ \\
\hline
\end{tabular}

Table 1: Comparison of fingertip pattern among Sickle cell patients and Controls.

\begin{tabular}{|c|c|c|c|c|c|c|c|c|c|c|}
\hline \multicolumn{10}{|c|}{ Right hand digits } \\
\hline & \multicolumn{2}{|c|}{ D1 } & \multicolumn{2}{c|}{ D2 } & \multicolumn{2}{c|}{ D3 } & \multicolumn{2}{c|}{ D4 } & \multicolumn{2}{c|}{ D5 } \\
\hline & SS & C & SS & C & SS & C & SS & C & SS & C \\
\hline Loops & $67.50 \%$ & $28.57 \%$ & $67.50 \%$ & $30.61 \%$ & $65.00 \%$ & $28.57 \%$ & $65.00 \%$ & $30.61 \%$ & $70.00 \%$ & $34.39 \%$ \\
\hline Whorls & $25.00 \%$ & $51.02 \%$ & $22.50 \%$ & $53.06 \%$ & $27.50 \%$ & $51.02 \%$ & $27.50 \%$ & $53.06 \%$ & $27.50 \%$ & $65.31 \%$ \\
\hline Arches & $7.50 \%$ & $20.41 \%$ & $10.00 \%$ & $16.32 \%$ & $7.50 \%$ & $20.41 \%$ & $7.50 \%$ & $16.32 \%$ & $2.50 \%$ & $0.00 \%$ \\
\hline \multicolumn{8}{|c|}{ Left hand digits } \\
\hline \multicolumn{8}{|c|}{ D2 } & \multicolumn{2}{c|}{ D3 } & \multicolumn{2}{c|}{ D4 } & \multicolumn{2}{c|}{ D5 } \\
\hline Loops & $65.00 \%$ & $30.61 \%$ & $65.00 \%$ & $28.57 \%$ & $37.50 \%$ & $53.06 \%$ & $67.50 \%$ & $26.53 \%$ & $72.50 \%$ & $36.73 \%$ \\
\hline Whorls & $27.50 \%$ & $53.06 \%$ & $27.50 \%$ & $51.02 \%$ & $10.00 \%$ & $32.65 \%$ & $22.50 \%$ & $51.02 \%$ & $27.50 \%$ & $63.26 \%$ \\
\hline Arches & $7.50 \%$ & $16.32 \%$ & $7.50 \%$ & $20.41 \%$ & $52.50 \%$ & $14.28 \%$ & $10.00 \%$ & $22.45 \%$ & $0.00 \%$ & $0.00 \%$ \\
\hline
\end{tabular}

D- Digit

Table 2: Frequencies of digital patterns for each digit of both hands in sickle cell (SS) and control group (C) in male population. 


\section{Open Access Journal of Dental Sciences}

\begin{tabular}{|c|c|c|c|c|c|c|c|c|c|c|}
\hline \multicolumn{11}{|c|}{ Right hand digits } \\
\hline & \multicolumn{2}{|c|}{ D1 } & \multicolumn{2}{|c|}{ D2 } & \multicolumn{2}{|c|}{ D3 } & \multicolumn{2}{|c|}{ D4 } & \multicolumn{2}{|c|}{ D5 } \\
\hline & SS & C & SS & C & SS & C & SS & C & SS & C \\
\hline Loops & $65.71 \%$ & $34.61 \%$ & $62.86 \%$ & $30.77 \%$ & $65.71 \%$ & $30.77 \%$ & $68.57 \%$ & $30.77 \%$ & $71.43 \%$ & $30.77 \%$ \\
\hline Whorls & $25.71 \%$ & $53.85 \%$ & $25.71 \%$ & $57.69 \%$ & $22.86 \%$ & $57.69 \%$ & $22.86 \%$ & $53.85 \%$ & $28.57 \%$ & $65.38 \%$ \\
\hline Arches & $80.57 \%$ & $11.54 \%$ & $11.43 \%$ & $11.54 \%$ & $11.43 \%$ & $11.54 \%$ & $8.57 \%$ & $15.38 \%$ & $0.00 \%$ & $3.85 \%$ \\
\hline \multicolumn{11}{|c|}{ Left hand digits } \\
\hline & \multicolumn{2}{|c|}{ D1 } & \multicolumn{2}{|c|}{ D2 } & \multicolumn{2}{|c|}{ D3 } & \multicolumn{2}{|c|}{ D4 } & \multicolumn{2}{|c|}{ D5 } \\
\hline & SS & C & SS & C & SS & C & SS & C & SS & C \\
\hline Loops & $31.43 \%$ & $57.69 \%$ & $65.71 \%$ & $30.77 \%$ & $68.57 \%$ & $30.77 \%$ & $65.71 \%$ & $34.61 \%$ & $68.57 \%$ & $34.61 \%$ \\
\hline Whorls & $60.00 \%$ & $26.92 \%$ & $22.86 \%$ & $53.85 \%$ & $22.86 \%$ & $53.85 \%$ & $22.86 \%$ & $53.85 \%$ & $31.43 \%$ & $65.38 \%$ \\
\hline Arches & $8.57 \%$ & $15.38 \%$ & $11.43 \%$ & $15.38 \%$ & $8.57 \%$ & $15.38 \%$ & $11.43 \%$ & $11.54 \%$ & $0.00 \%$ & $0.00 \%$ \\
\hline
\end{tabular}

Table 3: Frequencies of digital patterns for each digit of both hands in sickle cell (SS) and control group (C) in female population.

\section{Atd angle}

The mean values for 'atd' angle for both males and females were increased in sickle cell anemia. The males and females combined series showed higher mean values in sickle cell anemia. Overall 'atd' angle showed significant increase in sickle cell anemic patients and was highly significant (Table 4).

\begin{tabular}{|c|c|c|c|c|c|c|c|}
\hline \multirow{2}{*}{ Sex } & \multirow{2}{*}{ Side } & \multicolumn{2}{|c|}{ Sickle cell patients } & \multicolumn{2}{c|}{ Controls } & \multirow{2}{*}{ Unpaired t-test value } & \multirow{2}{*}{ P value } \\
\cline { 3 - 6 } & & Mean & SD & Mean & SD & & \\
\hline \multirow{3}{*}{ Male } & Right & 57.2 & 1.305 & 46.22 & 4.896 & 13.777 & $0.000, \mathrm{~S}$ \\
\cline { 2 - 7 } & Left & 57.55 & 1.552 & 46.22 & 4.048 & 16.713 & $0.000, \mathrm{~S}$ \\
\cline { 2 - 7 } & Right + Left & 57.38 & 1.43 & 46.22 & 4.47 & 21.443 & $0.000, \mathrm{~S}$ \\
\hline \multirow{3}{*}{ Female } & Right & 56.91 & 1.245 & 46.54 & 3.992 & 14.485 & $0.000, \mathrm{~S}$ \\
\cline { 2 - 7 } & Left & 56.83 & 1.654 & 48.65 & 4.638 & 9.662 & $0.000, \mathrm{~S}$ \\
\cline { 2 - 7 } & Right + Left & 56.87 & 1.45 & 47.6 & 4.42 & 16.418 & $0.000, \mathrm{~S}$ \\
\hline Overall & Right & 57.07 & 1.28 & 46.33 & 4.58 & 19.559 & $0.000, \mathrm{~S}$ \\
\hline (Male + Female) & Left & 57.21 & 1.63 & 47.07 & 4.39 & 18.752 & $0.000, \mathrm{~S}$ \\
\hline & Right + Left & 57.14 & 1.46 & 46.7 & 4.48 & 27.136 & $0.000, \mathrm{~S}$ \\
\hline
\end{tabular}

Table 4: Comparison of 'atd angle' among Sickle cell patients and Controls.

\section{a-b ridge Count}

Increased mean values were observed for sickle males and females and also in males and females combined

series of sicklers indicating significant increase in overall ' $a-b$ ' ridge count in sicklers than controls (Table 5).

\begin{tabular}{|c|c|c|c|c|c|c|c|}
\hline \multirow{2}{*}{ Sex } & \multirow{2}{*}{ Side } & \multicolumn{2}{|c|}{ Sickle cell patients } & \multicolumn{2}{c|}{ Controls } & \multirow{2}{*}{ Unpaired t-test value } & \multirow{2}{*}{ P value } \\
\cline { 2 - 7 } & & Mean & SD & Mean & SD & & \\
\hline \multirow{3}{*}{ Male } & Right & 41.6 & 2.44 & 35.49 & 1.43 & 14.715 & $0.000, \mathrm{~S}$ \\
\cline { 2 - 7 } & Left & 41.42 & 2.55 & 35.67 & 1.66 & 12.813 & $0.000, \mathrm{~S}$ \\
\cline { 2 - 7 } & Right + Left & 41.51 & 2.48 & 35.58 & 1.55 & 19.472 & $0.000, \mathrm{~S}$ \\
\hline \multirow{3}{*}{ Female } & Right & 42.06 & 1.63 & 34.62 & 1.55 & 17.998 & $0.000, \mathrm{~S}$ \\
\cline { 2 - 7 } & Left & 42.26 & 1.97 & 35.5 & 1.24 & 15.364 & $0.000, \mathrm{~S}$ \\
\cline { 2 - 7 } & Right + Left & 42.16 & 1.8 & 35.06 & 1.46 & 23.306 & $0.000, \mathrm{~S}$ \\
\hline Overall & Right & 41.81 & 2.1 & 35.19 & 1.52 & 22.115 & $0.000, \mathrm{~S}$ \\
\hline (Male + Female) & Left & 41.81 & 2.32 & 35.61 & 1.52 & 19.359 & $0.000, \mathrm{~S}$ \\
\hline & Right + Left & 41.81 & 2.21 & 35.4 & 1.53 & 29.207 & $0.000, \mathrm{~S}$ \\
\hline
\end{tabular}

Table 5: Comparison of 'a-b' ridge count among Sickle cell patients and Controls. 


\section{Open Access Journal of Dental Sciences}

\section{Discussion}

Sickle cell disease is the most common of the hereditary blood disorders. Sickle cell anemia (SCA) is genetic disease that results from substitution of valine from glutamic acid in the $\beta$ - globulin chain of the haemoglobin molecule [3]. In India the $\beta$ gene is more prevalent and prevalence rate varies from $0-40 \%$ in different population group. Chhattisgarh state is also believed to have a higher prevalence rate of $14-22 \%$ [4]. Our review found sufficient data to support strong dermatoglyphic relationship with sickle cell anemia, in general.

The examination of dermatoglyphics does not involve physical pain or economical burden for patients [7]. The other most important parameter of dermatoglyphics is the inheritance. All the physical features of the human body including the dermatoglyphics are inherited as per the laws propounded by Mendel. Since, very little work was done on dermatoglyphic features in sickle cell anemia, the present study was undertaken to determine an association between dermatoglyphic traits and sickle cell anemia. In the sickle cell male group, the arches were less frequent whereas the loops and whorls were more frequent.The result is closely related with the fact that the total fingerprint ridges and the absolute finger ridges were more numerous in the sickle cell male group. Interestingly, we found similar results in female sickle cell group though few variations did exist. Our study reported an increase in the value of 'atd' angle in sickle cell patients (mean $57.14^{\circ}$ ) as compared to controls (mean $46.7^{\circ}$ ) and the difference was statistically significant. The features of dermatoglyphics also express the correlation in many somatic, physiological, neurological and cytological afflictions and syndromes. High frequency of arches are often associated with Cat-Cry-Syndrome [8,9]; the total fingerprint ridges are numerous in patients with Turner's syndrome [10] and high finger ridge count is commonly recorded with trisomy of $\mathrm{X}$ chromosome. Dermatoglyphics has drawn attention in the field of dentistry and has been used to unveil oral diseases like dental caries, oral cancer, bruxism, malocclusion, anomalies of teeth, cleft lip, cleft palate, periodontal disease, dental fluorosis and also in unveiling truth with forensic odontology [11].

The most famous of ancient finger print designs are carvings on the wall of Neothalic burial passage, situated on the island of Brittany L'iie de Gavr'inis, its inner walls are covered with incised designs of circular patterns, spirals, arches, sinuous and straight lines occurring on various combinations [12]. Dermatoglyphic data has long been recognized as valuable genetic marker both in the study of population relationships as well as in clinical studies. Because of their inherent advantages over other biological markers, dermatoglyphics have been utilized by investigators from a number of different scientific disciplines. Dermatoglyphics can be traced back to 1892 , when one of the most original biologists of his time Sir Francis Galton, a cousin of Charles Darwin, published his work on fingerprints. The study was latter on termed as Dermatoglyphics by Harold Cummins [13], even though the process of finger print identification had already in use for several hundred years [13]. The present study is correlated with previous work which observed significant high frequency of whorls in Nigerian sickle cell group [8]. An increase in the mean value of a-b ridge count in sickle cell patients (57.14) as compared to controls (46.70) was observed with statistically significant difference. The dermatoglyphic characteristics of the Indian sickle cell anemia group are different from those of the Nigerian sickle cell group as increase in the value of atd angle is compared with the Nigerian study, which reported a decrease in the value of 'atd' angle. This can be explained as dermatoglyphics have been shown to have ethnic and racial variations. It is possible then that an ethnicity sensitive sample would yield a different result.

The results show that dermatoglyphics are helpful in the diagnosis of sickle cell anemia because several dermatoglyphic characteristics in patients with sickle cell are statistically different from those in normal persons. And on the whole our study along with that of Oladipo, et al. [8] has shown certain specific association between sickle cell and ridges indicating that genes are responsible for this disease [8]. The dermatoglyphic parameters which have shown association with sickle cell as diagnostic aid will be of limited use at this stage, more detailed studies in different populations are desirable. Epidermal ridges are formed between 11-24 weeks of gestation and after this period epidermal ridges do not change [14]. Since skin and brain develop from same ectoderm, dermatoglyphic variations are informative for early developmental brain disturbances [15]. However, there are some methodological limitations, which are inherent to many studies of this kind. They include: small sample size and limited number of variables for study. Another limitation is that the study groups are not homogenous in terms of their ethnicity. The heterogenous samples may some extent distort as dermatoglyphic characteristics are usually ethnicity-specific. If both cases and controls have been drawn from same ethnic group, the results might have more validity. Despite these limitations, the study had methodological strengths including use of three study groups drawn from natural 


\section{Open Access Journal of Dental Sciences}

population. The dermatoglyphic characteristics, which have shown association with sickle cell anemia as diagnostic aid will be of limited use at this stage. Further investigations in different ethnic groups are desirable. The study gives some directions to work further on this issue. The advancement in the field of computer software and scanner technology may yield new directions and techniques in dermatoglyphic research.

\section{Conclusion}

It is suggested by the result of this study that sickle cell anaemia should be included in the list of the congenital and genetic defects that have demonstrated specific dermatoglyphic patterns. However, field studies using sample frame across geographic and sociocultural groups with bigger and ethnicity sensitive samples may give opportunity for more definitive deductions. Dermatoglyphic diagnosis of Sickle cell anemia will be of a great value and help at community level as there is a higher prevalence of this disease in Chhattisgarh state and since it is a non invasive tool can be used at community level easily. "Palmistry isn't only about character analysis or fortune telling, it can act as a powerful non invasive tool in diagnosis and preventing illness."

\section{References}

1. Cummins H, Midlo C (1943) Fingertips, Palms and soles- An introduction to dermatoglyphics. Philadelphia: Blackiston Company 11-15.

2. Herschel WJ (1880) Skin furrows on the hand. Nature 23: 76.

3. Pauling L, Itano HA, Singer SJ, Wells IC (1949) Sickle cell anemia, a molecular disease. Science 110(2865): 543-548.

4. Patra PK, Chauhan VS, Khodiar PK, Dalla AR, Serjean GR (2011) Screening for the sickle cell gene in Chhattisgarh state, India: an approach to a major public health problem. Comm Genet 2(3): 147-151.

5. Panchekina EA, Benfer RA, Vershoubskaya GG, Kozlov AI (2000) Genetic and environmental influence on symmetry of dermatoglyphic traits. Am J Phys Anthropol 111(4): 531-543.
6. Bosco JI, Rajangam S, Shankar J, Thomas IM (2001) Dermatoglyphics in 46, XY females. J Indian Med Assoc 99(8): 418-420.

7. Stough TR, Seely JR (1969) Dermatoglyphics in medicine. Clin Pediatr 8: 32-41.

8. Oladipo GS, Olabiyi O, Oremosu AA, Norohnna CC, Okanlawo AO, et al. (2007) Sickle-cell anaemia in Nigera: Dermatoglyphic analysis of 90 cases. Afr J Biochem 1(4): 54-59.

9. Schaumann B, Alter M (1976) Dermatoglyphics in medical disorders, Springer Verlag, BerlinHeidelberg-New York 1-59.

10. Penrose LS (1963) Fingerprint, Palm and Chromosomes. Nature 197: 933-938.

11. Ceena DE, Junaid A, Nandita S, Almas B (2013) Dermatoglyphics in Dentistry- A review. Int J Cur Res Rev 5(21): 30-33.

12. Holt SB (1961) Dermatoglyphic pattern, eds. Genitical variations in human populations. Pregarnon: oxford 791.

13. Cummins H, Midlo C (1962) Palmar and planter epidermal configuration (Dermatoglyphics) in European, Americans. Am J Phys-Anthropol 9: 471502.

14. Babler WJ (1991) Embryological development of epidermal ridges and their configuration. In: CC Plato (Eds.), Dermatoglyphics: Science in transition $2^{\text {nd }}$ (Edn.), New York: Wiley liss 27: 95-112.

15. Van CJ, Baare WF, HU Ishoff $P$, Haag J, Balaz SJ, et al. (2001) Differentiating between low and high susceptibility to Schizophrenia in twins: The significance of dermatoglyphic indices in the relation to other determinants of brain development. Schizophr Res 52(3): 181-193. 